\title{
DEVELOPING COLLOCATIONAL AND PHONOLOGICAL COMPETENCES OF EMERGING TEACHERS OF ENGLISH AS A FOREIGN LANGUAGE THROUGH COGNITIVE APPROACH TO PROCESSING MULTI-WORD UNITS
}

\section{Irisa Berga}

Riga Teacher Training and Educational Management Academy

\begin{abstract}
This paper addresses unresolved issues in the acquisition, processing and use of multi-word units which account for the learner's idiomatic, natural language. The aim of the study is to argue for an analytic instructional approach to developing the trainee teacher's collocational and phonological competences through the medium of the native language employing a set of didactic and linguistic techniques like etymological, phonological, structural, lexical and semantic dissection of multi-word units. Research results imply that analytic processing of multi-word units relate moderately to the enhancement of the learner's collocational and phonological competences though relations between formal instruction and the language proficiency level may be partly obscured by the probable exposure of the learner to multi-word units in informal settings.
\end{abstract}

Keywords: collocational and phonological competence, lexical, semantic and syntactic valency, idiomaticity, multi-word units.

\section{Introduction}

Vocabulary acquisition is one of the most basic and fundamental tasks in foreign language learning. Moreover, it is absolutely essential that emerging teachers of English as a foreign language (hereinafter EFL) be proficient in their target language. Having reached an advanced level of English grammar the trainee teacher may sound very intermediate due to the restricted repertoire of their vocabulary, therefore the major task of teacher trainers is to help them move from an intermediate plateau to an advanced level of English language proficiency and assist them in their long journey towards the use of multi-word units (hereinafter MWUs) needed for idiomatic, native-like language. To reach an advanced level of the English language proficiency indispensable for an emerging teacher of EFL developing collocational and phonological competences of the foreign language learner are essential issues to be tackled. Within the framework of English lexicology course offered to trainee teachers of EFL the aforesaid issues under discussion pose a problem regarding the contents of the subject matter as well as didactic and methodological aspects, including syllabus design.

The emergence of corpus linguistics has shifted the attention to naturally occurring language data (McEnery et al., 2006:7), which is especially important in such areas of linguistic investigation as multi-word units, collocations, frequency and phraseology (Hunston, 2002:20). According to applied linguists naturally occurring linguistic phenomena arguably refer to probable language 
embracing conventionally used word combinations and partnerships instead of possible language included in traditional structure-based textbooks. The preponderance of evidence suggests as well as theoreticians and practitioners are unanimous in the decision on the point that naturally occurring corpora-based linguistic data should lay a firm foundation for classroom practices both in terms of acquiring and teaching lexis.

The present study reports an experiment involving 60 students - trainee teachers of EFL over a period of 3 years within the framework of the study subprogramme 'Teacher of English as a foreign language at basic school' to estimate the extent to which the acquisition of MWUs such as collocations, idioms, phrasal verbs, social formulae, institutionalised utterances, discourse markers and other formulaic sequences can help trainee teachers become proficient language users. During the experiment the trainee teachers were exposed to vast linguistic input in the form of a variety of MWUs and were administered questionnaires pertaining to their insights into optimal classroom techniques as well as their experiential knowledge of lexis acquisition. The experiment was conducted within the framework of lexical approach advocated by M.Lewis (2002) as opposed to conventional structural or grammar approach, nevertheless, the students - trainee teachers were provided with opportunities to consider the relevance of the ideas of lexical approach to their own teaching context and evaluate the proposed approach. The experiment was aimed at verifying the fundamental principle of lexical approach: how awareness and scrutiny of naturally occurring linguistic data might contribute to language acquisition.

The aim of the study is to develop an analytic cognitive approach to teaching lexis on the basis of typological and contrastive linguistics involving etymological, phonological and structural scrutiny of MWUs as well as dissection of lexical, semantic and syntactic valency of words constituting them. Materials and methods include two principal groups of didactic and linguistic tenets, which may overlap but are worth being distinguished. Didactic principles employed in this study include scientific, analytic and systemic techniques as well as contrastive and comparative analysis (Markus, 2004). Methods of linguistic analysis include comparative and contrastive study of English and Latvian MWUs aimed at revealing the specificity as well as universality of the metaphoric use of words and concepts involving etymological scrutiny of the origin of idiomatic expressions as well as phonological and structural scrutiny of MWUs. The approach proposed in the study could be referred to as an analytic (as opposed to holistic), cognitive and exploratory approach of juxtaposing or relating the linguistic phenomena in a foreign language to those of one's mother tongue.

Dissection of lexical, semantic, and syntactic valency of words within collocations was introduced due to absence of the notion of collocation in the Latvian linguistic discourse. Seeking for native counterparts of English MWUs 
was also applied for mnemonic purposes and activating cognitive and creative mental processes.

The major task set for the study was to test how awareness of linguistic phenomena and relevant didactic techniques might improve trainee teachers' language skills. Therein lies the research question: how can linguistic theory help trainee teachers of EFL become proficient language users? Given the theoretical conceptualisations (Van Patten, 2004; Wray, 2000, 2002, 2005; Schmitt, 2008; Thornbury, 2002, 2005; Cobb, 2007; O'Keeffe et al., 2007) and the author's experiential knowledge acquired in practical pedagogical activities, one may assume that noticing, processing and use of MWUs might significantly contribute to the advancement of the learner's foreign language mastery, thereby enhancing his/her collocational and phonological competences as well as building his/her methodological competence due to operating cognitive processes and activating personal attributes (Kumaravadively, 1994, 2003; Beaumont, 2005; Swan, 2013; Berga, 2011). The aforementioned assumption fits in the so-called Fundamental Similarity Hypothesis between the acquisition of one's mother tongue and a foreign language proposed by Bill Van Patten (2004), since foreign language learners rely largely on their native language acquisition experience. Moreover, the more creative and intellectual endeavour is involved in the acquisition process of a foreign language, the more likely it is facilitated. Consequently, the object of the research is the topical and much debated issue of processing and use of MWUs in the acquisition process of lexis (Wray, 2005; Lewis, 2000, 2002; Schmitt, 2008).

\section{Lexical approach versus structural approach}

The fundamental principles of lexical approach defined by M. Lewis (2002) lay the basis of the present study and can be enumerated as follows:

* the whole grammar/vocabulary as well as S.Krashen's learning/acquisition dichotomies are invalid and N.Chomsky's competence/performance distinction is unscientific;

* each word has its own grammar as language consists of grammaticalised lexis, not lexicalised grammar;

* all language lies on a spectrum between what is fixed and what is variable, and there are many degrees of fixedness and generalization (Lewis, 2000:1517, 44-45; Lewis, 2002, vi, 20-21, 97-100).

Central to the lexical approach is the focus on teaching real English - a shift away from the artificial language found in traditional English language teaching textbooks.

The theoretical grounding of the research proposed by the author of this study within the framework of lexical approach is deep-rooted in language acquisition theories like Contextual Difference Hypothesis (Brown, 1973: 106), wherein the native language acquisition is seen as a unique process, or, on the contrary, as 
B. McLaughlin (1984:219) concludes that foreign language learners 'pass through essentially the same development stages as children do acquiring their mother tongue', on Fundamental Similarity Hypothesis. Van Patten (2004) points out that both native and foreign language acquisition processes share the same characteristics: 'both processes are input-dependent and demonstrate poverty of stimulus and internal grammar is impervious to direct and explicit outside influences' (Van Patten, 2004:14).

Though Fundamental Similarity Hypothesis does not suggest a direct reference to instruction, it does suggest that some instruction models are more effective than others (Van Patten, 2004:15). Moreover, Gass and Selinker (2008, cited in Walter 2012:85) in a narrative review of literature, conclude that after early childhood, learning complex forms requires not only the processing of meaningful input but also explicit focus on linguistic phenomena. In addition, Spada and Tomita's (2010, cited in Walter 2012:85) meta-analysis concludes that explicit form-focused instruction leads to better learning of both simple and complex linguistic features than implicit instruction. Consequently, despite N. Chomsky's Universal Grammar theory (Chomsky, 1959, cited in Lightbown \& Spada, 1999:36-37), research proves that formal instruction might have some facilitating effect, it may speed up acquisition.

The foregoing findings suggest that formal instruction may lead to both learning and unconscious acquisition of English phraseology ultimately mastering its idiomaticity which, in its turn, accounts for fluent, idiomatic, native-like language indispensable for an emerging teacher of EFL.

\section{Diversity of terminology}

Contemporary linguistics abounds in diverse terminology regarding multi-word units, but they are often termed lexical chunks/clusters. 'Chunks/clusters of speech have been preassembled through repeated use and are now retrievable as single units' (Carter \& McCarthy, 2006:895; Thornbury, 2005:23). Labels include 'lexical phrases', 'prefabricated patterns', 'routine formulae', 'formulaic sequences', 'chunks'(O'Keeffe et al., 2007:63) as well as the more conventional labels such as '(restricted) collocations', 'fixed expressions', 'multi-word units/expressions', 'idioms', etc. Whatever the terminology, all seem to agree that multi-word phenomena are a fundamental feature of language use (O'Keeffe et al., 2007). Multi-word units normally function as meaningful units with a fixed or semi-fixed form and a various degree of idiomaticity/ idiomatic nature, while collocations are endowed with a looser kind of association. S.Thornbury (2002) claims that collocations are best seen as part of a continuum of strength of association: a continuum that moves from compound words (second-hand), through MWUs or lexical chunks (bits and pieces), including idioms (out of the blue) and phrasal verbs (log in), to collocations of more or less fixedness (set a new world record) (Thornbury, 2002:7). Similarly, Lewis 
(2002) defines collocations as 'readily observable phenomena', whereby certain words 'co-occur in natural text with greater than random frequency' determined by linguistic convention and can be distinguished as fully fixed such as to catch a cold, drug addict and more or less fixed such as blood/close/distant/near relative; learn by doing/by heart/by observation/by rote/ from experience (Lewis, 2002:47-67).

The terminology used by contemporary British and American applied linguists and methodologists may be even more variegated, ambiguous or non-uniform. Thus, you may encounter the terms like 'formulaic language/sequences, lexical phrases/chunks' (Wray, 2005); 'institutionalised expressions/holophrases', 'sentence heads/starters' (Lewis, 2002:99,111); 'social formulae, discourse markers, catchphrases, prefabricated chunks/prefabs' (Thornbury, 2005:23); 'word clusters' (Carter \& McCarthy, 2006:828-837). Lewis (2002) presents the taxonomy of the following lexical items: 'polywords' (by the way, upside down); 'collocations or word partnerships' (community service, absolutely convinced); 'institutionalised utterances' (We'll see, That'll do); 'sentence frames and heads' (Firstly..., Secondly..., Finally) (Lewis, 2002:90 - 96).

At the same time former Soviet linguists (A.Koonin, N.Amosova, V.Vinogradov, L.Vigotsky a.o.), including Russian and Latvian phraseologists normally adhere to conventional terminology such as set expression/phrase, phraseological unit, stable/fixed word group (Babich, 2006).

Thus, in the Explanatory Dictionary of Basic Linguistic Terminology of the Latvian language (VPSV, 2007) three entries for MWUs are made 'phraseological unit/phraseologism' defined as a lexically inseparable, relatively stable word combination in terms of components and structure, fossilised by traditional language use and the meaning of which or its components is usually transferred e.g. ar gariem zobiem (with long teeth meaning 'unwillingly' I.Berga's translation) and the second one - 'fixed word-group/phraseologism' defined as a word-group which carries the meaning and the functions of one word and the meaning of which differs from the sum of the lexical meanings of its components e.g. zili brinumi (blue miracles meaning 'miraculous' - I.Berga's translation) (VPSV, 2007:124, 371). The notion of 'idiom' is equalled to the term 'phraseologism' (ar gariem zobiem) (VPSV, 2008:148).

To avoid ambiguity the term of multi-word unit preferred by the author of this study shall be used to denote any relatively stable pre-constructed word combination the meaning of which or its separate components is partly or fully transferred such as make ends meet, part and parcel, as cool as a cucumber (Thornbury, 2005:23).

The term of collocation as a particular variety of MWUs, the profound analysis of which is given by Lewis (2000), shall be used additionally to denote the collocability of the word i.e. its ability to collocate with other words and cooccur with more than random frequency. The definition of collocations originally given by Firth (1953) is 'the company words keep' (quoted in Lewis, 
2000:48), or later by Lewis (2000:48) - 'the way words combine in predictable ways', or 'a word or phrase which is often used with another word or phrase, in a way that sounds correct to people who have spoken the language all their lives, but might not be expected from the meaning' (CALD, 2008:268) such as raging inflation, a burning ambition, hard frost (OCD, 2002:893; CALD, 2008:268). Although the idea of collocations goes back to 1950s, much of the current interest for linguists began with John Sinclair's work 'Corpus.Concordance.Collocation' (1991).

Collocations and colligations (defined as preferred grammatical configurations/patterns by Thornbury $(2002,136)$ together produce unitary meaningful strings or chunks of language which give substance to the 'idiom principle' formulated by Sinclair (1991) as 'a large store of ready-made lexicogrammatical chunks that actually create the text' (Sinclair, 1991:109).

In Latvian phraseology there is no counterpart for the notion of 'collocation', therefore within the framework of the present study the author suggests identifying links between the words or lexical, semantic and syntactic valency among words within collocations for the purposes of comparative and contrastive analysis of English and Latvian collocations.

Owing to its specificity the term of idiom shall be applied to those MWUs the meaning of which is fully transferred and none of its components is used in its lexical/literal meaning such as bite off more than you can chew; bite the bullet; once bitten, twice shy (CALD, 2008:714, 992).

The term of collocational competence shall be referred to the proven ability of the learner characterised by the learner's awareness, successful processing and proper use of MWUs. The concept was widely exploited by Lewis $(2000,2002)$ and can occasionally be encountered in linguistic discourse. Lewis's (2000) idea that 'any collocation is idiomatic and any idiom contains collocations' has been proved by scholars over centuries (Lewis 2000, 50-51).

Phonological competence can be defined as a receptive and/or productive competence in connected speech, which enhances the learner's understanding of fast and fluent speech (Kelly, 2000). The concept 'native-speaker phonological competence' is commonly used to describe the foreign language learner's ability of being aware and producing sound/phoneme changes like assimilation, simplification, contraction, linking, elision, juncture, liaison, intrusion, sound reduction etc. occurring in natural native speaker's language such as 'hafta, gonna, coulda, wouldja like ucupatea, whadjado, Febuary, gowoff' instead of 'have to, going to, could have, would you like a cup of tea, February, go off' and the like (Cauldwell, 2002, 2006; Roach, 2000; Underhill, 2005; Swan, 2006; Berga, 2009). 


\section{Core vocabulary}

During the experiment the contents of the subject matter, in this particular case, the lexicology course and prospective lexis syllabus at basic school was a pressing matter to attend to. The core vocabulary and the 'behaviour' of the basic words in MWUs, including collocations, idioms and other formulaic sequences turned out to be a major issue to be addressed first and foremost.

Why is the core vocabulary so important? Firstly, because of their frequent use: in English nearly 50 percent of all the words belong to the 100 most frequent ones, while about 83 percent belong to the top 3000 in a frequency list. In simple terms, there is a small number of very frequent words and a large number of very infrequent ones (Rundell, 2010:115). More importantly, the commoner words tend to have multiple uses and appear in all sorts of recurrent combinations (phrasal verbs, compounds, collocations, MWUs of every type). The aforesaid fact acts in compliance with Sinclair's (1991) well-known 'idiom principle': the notion that words (at least core words) are best seen not as bearers of meaning, but as participants in a range of 'prefabricated/semipreconstructed' phrases (Sinclair, 1991:109). Consequently, knowing a word means knowing not only its core meanings but also its 'behaviour'- its core uses and combinations.

Collocation illustrates the idiom principle and is an essential aspect of vocabulary acquisition. Being able to see what is frequent, noticing and raising awareness of collocates, processing them and eventually using them are extremely useful for the learner of English.

Basically, it is generally agreed that ideally language 'should be studied in authentic attested instances of use', eliciting from the authentic texts what is frequent and more likely to co-occur (Stubbs, 1996:23). Corpora, concordances, frequency lists offered by the computer age are an invaluable asset in providing evidence of frequency and probability of the use of lexical items. By analysing and interpreting concordance lines we can draw conclusions about what is typical usage of a particular word or phrase, about meaning distinctions of nearsynonyms, about the connection of meanings and patterns of usage (colligations), all in all, about the 'behaviour' of particular words (Hunston, 2002:42-52).

The availability and presence of such information account for the idiomaticity, fluency and proficiency of the learner's language.

\section{Etymological scrutiny of MWUs}

Etymological scrutiny and dissection of a specific variety of MWUs - idioms were employed as a means of motivation and mnemonics which trigger cognition and facilitate memorising. Finding native counterparts activated the 
learner's analytic and cognitive abilities which, in their turn, facilitated acquisition.

Idioms are identical in many languages, including Baltic and Germanic ones, as a number of them are rooted in Bible, folklore, myths of ancient Greeks and antique literature. Basically, they are originally linked to a particular place and time, specific event, consequently, they are idiosyncratic and individual and cannot be rendered word for word. Therefore, finding native counterparts involves a lot of creative mental effort, which contributes to acquisition of lexis, it usually arouses cognitive attitude. Thus, the biblical idiom cast pearls before swine, the Homeric phrases cross the Rubicon, Achilles heel, cut/untie the Gordian knot, the folklore-based phrase Jack of all trades have identical counterparts in Latvian mest pērles cūkām, pāriet Rubikonu, Ahileja papēdis, pārcirst Gordija mezglu, devinu amatu pratējs, while the English idioms throw in the towel, to be on tenterhooks present similar conceptual metaphors in Latvian though through another wording: mest plinti krümos (to throw the gun into the bushes - I.Berga's translation), bùt kā uz adatām/uzvilktam (to be like on needles/stretched - I.Berga's translation) (Reformatskis, 1974:94-100; OID, 2001:2,50,71, 145, 186, 396, 404).

Etymological dissection or simply origin of idioms bestows one with mnemonics, additional ardour and endeavour. Thus, the idiom to be on tenterhooks (to be in a state of suspense, anxiety) comes from cloth-making and weaving in which the finished material is stretched on a frame known as 'tenter' with the cloth being attached to it at the edges by means of 'tenter hooks' (Headway Advanced,1989:8)

\section{Structural scrutiny of MWUs}

As mentioned above word combinations of idiomatic, natural sounding speech may range from 'weak' (totally free) as see a man/film/car through the 'medium strength' as see a doctor, to the totally fixed and idiomatic ones as not to see the wood for the trees. All the combinations, apart from those at the very extremes can be called collocations (OCD, 2002, vii). Their structure seems to be worth noticing, scrutinising and dissecting. The following types of combinations (suggested by OCD, 2002, ix; Lewis, 2002:51; Thornbury, 2002:106-129) were detected and analysed by the trainee teachers of experimental groups:

* adjective + noun as in rich/plain food (Headway Advanced, 1989:64); brisk/harsh/strong light (OCD, 2002, ix); heavy rain but strong wind; a breath of fresh air but an open-air restaurant (Lewis, 2002:49);

* quantifier + noun as in a wink of sleep; a hint of trouble; a stroke of luck (Headway Advanced, 1989:77, 78); a bout of depression; a beam/ray of light (OCD, 2002, 893);

* verb + noun as in cast/emit/shed light (OCD, 2002, 893); submit/present a report (OCD, 2002:,647)); 
* noun + verb as in light gleams/shines/glows; wind howls, stomach churns, head throbs (OCD, 2002:463, 893);

* noun + noun as in a light source (OCD, 2002, ix); fire escape (Lewis, 2000:51); a book worm, tax rebate (Proficiency Masterclass, 1998:45);

* adverb + verb/ verb + adverb as in strongly/greatly/firmly recommend; entirely/fully investigate (Headway Advanced, 1989:64); examine thoroughly/properly/exhaustively (OCD, 2002:271-2);

* adverb + adjective as in terribly/awfully sorry; absolutely/quite/completely impossible (Headway Advanced, 1989:64); perfectly/environmentally safe (OCD, 2002, ix) etc.

Not all probable structural alternatives are enumerated here, some may contain more than two words. A special structural formation 'verb + particle' (adverb, prepositional phrase) is commonly related to phrasal verbs such as bestow on (give someone sth. valuable), embark on (start a new project), keep up appearances (pretend that everything is good) (Macmillan, 2005:27, 141, 238).

\section{Phonological scrutiny of MWUs}

Though idiomatic, natural language and MWUs constituting it are endowed with phonological unity/entity and pronunciation is considered to be integral in idiomatic language (Lewis, 2002:55), its dissecting after listening passages proved to be an additional tenet of noticing, raising awareness of sound/phoneme changes of natural/idiomatic speech which eventually enhanced the learner - trainee teacher's phonological competence both receptively and productively.

Thus, when pronouncing the social formula mind your head or the institutionalised utterance we'll go empty-handed again at a normal, natural speed, the following sound changes or phonetic erosion will occur: coalescence/fusion of two sounds [d] and [j] producing [d3]; the use of the weak form of the possessive pronoun your instead of the strong form; the sound [w] will be inserted between the two words go and empty-handed (intrusive [w]), and the contracted form [wi:l] will be used instead of the full form we will.

For the purposes of comparative and contrastive analysis the phenomena of sound reduction and assimilation were found in the Latvian language: the mutual adaptation of the articulation of neighbouring sounds as in aizskriet [ais:kriet] ('run away'), apgūt [abgu:t]('acquire'), svešs [sveš:] ('alien'), wherein the processes of regressive and progressive assimilation as well as reduction or weakening/loss of a segment as in interesants [intresants] ('interesting') take place (VPSV, 2007:313, 322,323).

Hence, natural sound simplification and reduction phenomena of connected speech were comprehended through listening to passages of idiomatic language, analysed and contrasted to the relevant phenomena of the native tongue, thereby enhancing phonological competence of the learner - emerging teacher of EFL. 


\section{Dissecting lexical, semantic and syntactic valency of words within collocations}

The concept of valency has been selected by the author of the study to denote links between words constituting word combinations termed collocations in contemporary English applied linguistic discourse. Latvian phraseology lacks the corresponding terminology; it was encountered in I.Oḷehnoviča's Doctoral thesis (2012), where the notion of collocation was defined as saistāmība (the ability of being linked - I.Berga's translation). Since 'The Explanatory Dictionary of Basic Linguistic Terminology' of the Latvian language (VPSV, 2007) does not provide any explanations or definitions of the terms of collocation and colligation, lexical, semantic and syntactic links between words in various word combinations seemed to be a sound basis for comparative and contrastive analysis of the relevant phenomena in both languages.

Lexical valency characterises links between the words in the collocation rancid butter, where rancid is a collocate of butter; similarly, the verb sanet (buzz) can be related only to the noun bite (bee). Thus, lexical valency is the ability of a word to be syntactically linked with the words of definite lexical meanings (VPSV, 2007:211).

Semantic valency is the ability of a word to collocate with the forms of definite semantic categories such as the verb sütīt (to send) can attract the name of the doer, the name of the direct object and the name of the addressee: māte süta dèlam vēstuli (mother sends her son a letter - I.Berga's translation) (VPSV, 2007:349). Lewis (2000) states that words do not combine with chosen words but with chosen meanings, similarly, Sinclair (1991) claims that many uses of words and phrases show a tendency to occur in a certain environment e.g. the verb happen is associated with unpleasant things (Lewis, 2002:232). This phenomenon is labelled as 'semantic prosody': when a word associates with a set of particular meanings/semantic fields. Thus, the adjective chilly may be associated with the following semantic fields: units of time, weather, ill people, watery things and can also be used metaphorically such as chilly afternoon, it's chilly, chilly patient, chilly bathtub, chilly reception (Lewis, 2002:232).

Syntactic valency as the ability of a word to be syntactically linked with the word forms of definite syntactic categories characterises links manifested in colligations wherein 'one word regularly co-occurs with a particular grammar pattern' (Lewis, 2002:137) or 'one lexical item may be primed to occur in or with a particular grammatical function' (Hoey, 2005:43). Thus, the class of verbs of perception such as hear, notice, see, watch enter into colligation with the sequence of an object + either the bare infinitive or the -ing form (Hoey, 2005) e.g.

- We heard visitors leave/ leaving;

- We noticed him walk away/ walking away. 
Similarly, in the Latvian language transitive verbs can attract an object in the accusative such as nest saini, lasìt grāmatu (carry a parcel, read a book I.Berga's translation), or attract a direct and indirect object as in sütìt draugam vesstuli, defined as a 'compound subordinate word-group' (send a letter to a friend- I.Berga's translation) (VPSV, 2007:338, 358). While traditional grammar operates with broad syntactic patterns such as tenses, where lexis fills the slots in the syntactic frames, within the lexical or word grammar approach the learner's attention is drawn to the syntactic constraints on the use of lexis. Consequently, the trainee teacher's attention is directed towards probable rather than possible language, thereby his/her language is made more fluent, naturalsounding and idiomatic.

\section{Conclusions and discussion}

After having surveyed research data and made a qualitative analysis of the results of the study (questionnaires, interviews, students-trainee teachers' presentations, essays, tests) one may conclude that in spite of being considered as a particular threat to intelligibility by scholars in favour of the use of English as a global language and lingua franca, the native speaker idiomatic language may still be regarded as an indicator of a high level of language proficiency especially indispensable for emerging teachers of EFL.

The hypothesis formulated at the start of the research which predicted that lexical approach to teaching language superseded the structural one was not fully confirmed but cannot be rejected at this stage either. The students-trainee teachers showed enthusiasm and appreciated stimulating ideas of lexical approach at the same time critically appraising and creatively adapting them to the needs of the national curriculum and the particular learning context.

The study reveals that the development of trainee teachers' collocational and phonological competences might benefit from activating cognitive and creative mental processes on the basis of comparative and contrastive analysis of linguistic data retrieved from corpora, concordances and corpus-based dictionaries/textbooks focusing on MWUs which present themselves as preassembled, naturally occurring word combinations.

Teaching lexis explicitly involving the learner's cognitive and creative mental processes, their analytic - contrastive and comparative abilities may lead to learning as well as unconscious acquisition of English phraseology ultimately mastering its idiomaticity which, in its turn, accounts for fluent, idiomatic, native-like language.

Implications for classroom practices regarding vocabulary acquisition suggested by the author of this study could be summarised as follows:

- explicit lexis teaching involving the learner's cognitive and creative mental processes and their analytic abilities of contrasting and comparing; 
- inductive lexis teaching which would involve noticing, awareness raising of MWUs and vast linguistic input;

- the native-like, non-analytic, holistic processing of MWUs could be extrapolated to processing of MWUs characteristic of a non-native speaker i.e. cognitive analytic mode of processing linguistic phenomena could also be approached holistically;

- it is essential that collocational and phonological competences be developed to make trainee teachers proficient language users concurrently developing their methodological competence on the basis of the newly- acquired and experiential knowledge of the subject matter;

- the trainee teacher's methodological competence should be enhanced by actualising their personal attributes and principled pragmatism i.e. being proactive and creative in designing syllabi, spotting the drawbacks of one best approach/method, critically appraising prescriptive methods as well as reflecting upon their own practices;

- vocabulary selection should be corpus-bound based on frequency lists, concordance lines and corpora-based textbooks/dictionaries embodying a wide range of texts and domains of reality as well as being appropriate for the given learning context;

- listening activities involving authentic language which abounds in readymade pre-constructed sequences and present phonological unity should be normally implemented into regular class aimed at raising awareness of idiomatic language and developing linguistic competences both receptively and productively.

\footnotetext{
References

1. Babich,G.N. (2006). Lexicology. A Current Guide. Ekaterinburg - Moscow: Belaja Medvedica, p. 101-112.

2. Beaumont, M. (2005). Methodological innovation, cultures of learning and teacher development. IATEFL Global Issues and Teacher Development SIGs. Development for Empowerment, Empowerment for Development. G. Hall (ed.). Brighton Event Papers, p. 4-10.

3. Berga, I. (2009). Integrating English phonology into language teaching. Conference Proceedings. Applied Linguistics for Specialised Discourse. International Scientific conference 22-23 May, 2009. Riga: the University of Latvia.

4. Berga, I. (2011). No iegūtām zināšanām uz profesionālām kompetencēm [From received and experiential knowledge to professional competences]. Society. Integration. Education. Proceedings of the International Scientific Conference. May $27^{\text {th }}-28^{\text {th }}$, 2011. Volume 1. Rēzekne: RA Izdevniecība, p. 44-53.

5. Brown, R. (1973). Development of the $1^{\text {st }}$ language in the human species. American psychologist 1973/28/97, p. 106.

6. Carter, R. \& McCarthy, M. (2006). Cambridge Grammar of English. A Comprehensive Guide. Spoken and Written English Grammar and Usage. Cambridge University Press.

7. Cauldwell, R. (2006). A Syllabus for Listening. Unpublished paper given at the $40^{\text {th }}$ International Annual IATEFL Conference, Harrogate, UK, April 11, 2006.
} 
8. Cauldwell, R. (2002). Phonology for listening: Relishing the Messy. Retrieved from: www.speechinaction.net.

9. Cobb, T. (2007). Computing of the vocabulary demands of L2 Reading. Language learning and technology 11/3, p. 38-63.

10. Hoey, M. (2005). Patterns of lexis in texts. Cambridge: Cambridge University Press.

11. Hunston, S. (2002). Corpora in Applied Linguistics. Cambridge: Cambridge University Press.

12. Kelly, G. (2000). How to teach pronunciation? Series editor Jeremy Harmer. Harlow: Pearson Education Limited. Longman.

13. Kumaravadively, B. (2003). Beyond methods: Macrostrategies for Language Teaching. New Haven: Yale University Press.

14. Kumaravadively, B. (1994). The post-method condition: (e)merging strategies for second/foreign language teaching. TESOL QUARTERLY 28/11, p.27-48.

15. Lewis, M. (2002). The Lexical Approach. The State of ELT and a Way Forward. Thomson:Heinle.

16. Lewis, M. (Ed.) (2000). Teaching collocations. Further Developments in the Lexical Approach. London: Language Teaching Publications.

17. Lightbown, P.M. \& Spada, N. (1999). How languages are learned. 2nd edition. Oxford: Oxford University Press.

18. Markus, D. (2004). Phonological and methodological opposition of the short and long vowels in the Latvian language. RPIVA Zinätniskie raksti IV [RTTEMA Scientific articles]. Rīga: RPIVA, p. 198- 203.

19. McEnery, T. et al. (2006). Corpus-based Language Studies: An Advanced Resource Book. London: Routledge.

20. McLaughlin, B. (1984). Second language acquisition in childhood. Preschool Children.Vol. 1, p.219.

21. O'Keeffe, A., McCarthy, M. \& Carter, R. (2007). From Corpus to Classroom: Language Use and Language Teaching. Cambridge: Cambridge University Press.

22. Ol̦ehnoviča, I. (2012). Phraseological units in English and Latvian Newspapers: the Semantic Aspect. Doctoral Thesis. Daugavpils: Daugavpils Universitātes Akadēmiskais apgāds.

23. Reformatskis, A. (1975). Ievads valodniecībā [ Introduction into linguistics]. Translated from Russian. Rīga: Zvaigzne.

24. Roach, P. (2000). English Phonetics and Phonology: A Practical Course. Third edition. Cambridge: Cambridge University Press.

25. Rundell, M. (2010). How many words do you need to know? IATEFL 2009 Cardiff Conference Selections. Edited by Briony Beaven. Canterbury: IATEFL, p.114-116.

26. Schmitt, N. (2008). Review article: Instructed second language learning. Language Teaching Research, p. 329-363.

27. Sinclair, J. (1991). Corpus, Concordance, Collocation. Oxford: Oxford University Press.

28. Stubbs, M. (1996). Text and Corpus Analysis. Oxford: Blackwell.

29. Swan, M. (2013). Grammar doesn't have to be grey. IATEFL 2012 Glasgow Conference Selections. Tania Pattison (Ed.). Canterbury: IATEFL, p.60-62.

30. Swan, M. (2005). What is happening in English? English Teaching Professional. Issue 40, September 2005, p. 4-6.

31. Thornbury, S. (2005). How to teach speaking? Series editor Jeremy Harmer. Pearson Education Limited, Longman.

32. Thornbury, S. (2002). How to teach vocabulary? Series editor Jeremy Harmer. Harlow: Pearson Education Limited, Longman. 
33. Underhill, A. (2005). Sound Foundations. Learning and Teaching pronunciation. Macmillan Publishers Limited.

34. Van Patten, B. (2004). Plenary: The Fundamental Similarity Hypothesis. IATEFFL 2004 Liverpool Conference Selections. Pulverness Alan (ed.). Canterbury: IATEFL, p. 14-15.

35. Walter, C. ( 2012). Plenary: Should we be planning to teach grammar? If so, how? IATEFL 2011 Brighton Conference Selections. Tania Pattison (Ed.) Canterbury: IATEFL, p. 82-89.

36. Wray, A. (2005). Idiomaticity in a L2: linguistic processing as a predictor of success. Unpublished paper given at the IATEFL $39^{\text {th }}$ Annual Conference, Cardiff, April, 2005. Cardiff University.

37. Wray, A. (2002). Formulaic language and the lexicon. Cambridge: Cambridge University Press.

38. Wray, A.(2000). Formulaic sequences in second language teaching: principle and practice. Applied Linguistics 21(4), p. 463-489.

\section{Abbreviations for information sources providing examples:}

CALD (2008). Cambridge Advanced Learner's Dictionary. Third edition. Cambridge University Press.

Headway Advanced (1989). Headway Advanced. Workbook. John \& Liz Soars. Oxford: Oxford University Press.

Macmillan (2005). Macmillan Phrasal Verbs plus. Macmillan Publishers Limited.

OCD (2002). Oxford Collocations Dictionary for students of English. Oxford: Oxford University Press.

OID (2001). Oxford Idioms Dictionary for learners of English. Oxford: Oxford University Press.

Proficiency Masterclass (1998). Proficiency Masterclass Workbook with answers. Kathy Gude and Michael Duckworth. Oxford: Oxford University Press.

VPSV (2007). Valodniecības pamatterminu skaidrojošă vārdnīca. Vārdn̄̄cas autori: O.Bušs, D.Joma, A.Kalnača, I.Lokmane, D.Markus, I.Pūtele, V.Skujiņa. Sastādījis autoru kolektīvs V.Skujiņas vadībā. Rīga: LU Latviešu Valodas institūts.

Mg.philol., Mg.paed.

Irisa Berga
Riga Teacher Training and Educational Management Academy, Rīga,Imantas 7.līnija 1, LV 1083 e-mail: irisaberga@inbox.lv; irisa.berga@rpiva.lv Mobile phone: (371) 29228938 